\section{Kathy Michell}

Prof. Kathy Michell,

Department of

Construction Economics

and Management, Upper

Campus, University of

Cape Town, Private Bag

X3, Rondebosch 7701,

South Africa.

Phone: 021650 3444, Email:

Kathy.Michell@uct.ac.za

\section{Raymond Nkado}

Prof. Rymond Nkado, School

of Construction Economics and Management, University of the Witwatersrand, 1 Jan Smuts Avenue, Braamfontein 2000, Johannesburg,

South Africa.

Phone: 0117177011 , Email:

raymond.nkado@wits.ac.za

\section{Kenneth Bowazi}

Mr Kenneth Bowasi,

Built Environment and

Mechanical Engineering,

Newham Sixth Form College,

Prince Regent Lane, London,

UK, E13 8SG.

Phone: 02074734110 ,

Email: info@newvic.ac.uk

DOI: http://dx.doi.

org/10.18820/24150487/as26i1.8

ISSN: 1023-0564

e-ISSN: 2415-0487

Acta Structilia 2019 26(1): 201-201

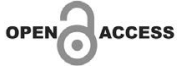

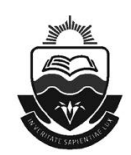

Published by the UFS

http://journals.ufs.ac.za/index.php/as

(c) Creative Commons With Attribution (CC-BY)

How to cite: Michell, K., Nkado, R. \& Bowazi, K. 2019. Book review. Quantity surveying pre-contract administration. Publisher: Fanie Buys. First publication: 2016. Acta Structilia, 26(1), pp. 201-201.

\section{Quantity surveying pre- contract administration by Fanie Buys First publication: 2016}

\section{Prof. Kathy Michell}

Following on the success of Prof. Fanie Buys's first book that provided worked examples to the measuring of building work of a single residential building, this book entitled Quantity surveying, precontract administration builds on his previous work by utilising a three-storey reinforced concrete structure building as the basis for the worked examples. This book provides the reader with a set of clear worked solutions for the estimates (square-metre and elemental), the feasibility study, the measurement of, and the final Bills of Quantities for a three-storey shop and office building. In doing so, it provides a comprehensive collection of the fundamental 'measurement' building blocks required in a professional quantity surveyor's 'toolbox'. Moreover, it highlights the underlying philosophical differences in one's approach to the measurement of building works at the different stages of design, thereby providing a useful benchmark for students and practitioners alike in making the connections between the fundamental theory of measurement 
and its practical application. The book will serve as an extremely useful resource for quantity surveying students, lecturers and candidate quantity surveyors needing to develop and/or enhance their fundamental understanding of the process of measurement and the associated standard documentation processes in estimates, feasibility studies and Bills of Quantities.

\section{Prof. Raymond Nkado}

Quantity surveying pre-contract administration places the measuring of building work within the context of assessing the feasibility of a project. Prof. Buys takes the reader through the key components of the quantity surveyor's cost advice roles at pre-contract stages, including: establishing early estimates of project cost, assessing the feasibility of the project, refining the estimate through elemental analysis as more design and specification information becomes available, and producing and pricing the full Bills of Quantities for project procurement. A three-storey commercial office project is aptly used to illustrate each of the above processes. There are ample side notes to clarify the choice of parameters as well as to guide the reader through the measurement processes undertaken. The text incorporates the latest guide to cost estimating issued by the Association of South African Quantity Surveyors, among other relevant reference materials. Future editions could give more detailed guidance to readers on calculations of contract escalations, net present value, the internal rate of return and choice of cash-flow factors for feasibility analysis. This book is highly recommended for honours students of construction studies (quantity surveying, construction management, property management), lecturers and practitioners. Candidates in training for registration as professional quantity surveyors with the South African Council for the Quantity Surveying Profession (SACQSP) will also find this a particularly useful text.

\section{Mr Kenneth Bowazi}

The book Quantity surveying, pre-contract administration covers very important aspects of the estimating and measuring processes relevant and applicable to any construction project. It takes one through the whole thought process of coming up with a cost of proposed building works from inception to completion. It has very detailed drawings, including window, door and finishes schedules that give more details and facilitate the job of the estimator to provide a better estimate. Estimating, including the common methods of estimating, is well discussed in this book. One of the most important aspects included in this book is the feasibility study which enables decision-makers on 
inception to make critical decisions whether to proceed or not with a project at hand. The sample feasibility study included is very educative. Besides feasibility studies, the Bill of Quantities and dimension paper with calculations of quantities has been included and makes those in academia and practice understand the processes well. Note that, while this book will help the industry in South Africa, a great part thereof can also be used for teaching and learning worldwide. This book remains a suitable tool for practising professionals, students, and teachers in tertiary education. 